\title{
Front Matter: Volume 9710
}

, "Front Matter: Volume 9710," Proc. SPIE 9710, Optical Elastography and Tissue Biomechanics III, 971001 (24 June 2016); doi: 10.1117/12.2239750

SPIE. Event: SPIE BiOS, 2016, San Francisco, California, United States 


\title{
PROGRESS IN BIOMEDICAL OPTICS AND IMAGING
}

\section{Optical Elastography and Tissue Biomechanics III}

\author{
Kirill V. Larin \\ David D. Sampson \\ Editors
}

13-15 February 2016

San Francisco, California, United States

Sponsored by

SPIE

Cosponsored by

Thorlabs, Inc.

Published by

SPIE 
The papers in this volume were part of the technical conference cited on the cover and title page. Papers were selected and subject to review by the editors and conference program committee. Some conference presentations may not be available for publication. Additional papers and presentation recordings may be available online in the SPIE Digital Library at SPIEDigitallibrary.org.

The papers reflect the work and thoughts of the authors and are published herein as submitted. The publisher is not responsible for the validity of the information or for any outcomes resulting from reliance thereon.

Please use the following format to cite material from these proceedings:

Author(s), "Title of Paper," in Optical Elastography and Tissue Biomechanics III, edited by Kirill V. Larin, David D. Sampson, Proceedings of SPIE Vol. 9710 (SPIE, Bellingham, WA, 2016) Six-digit Artic le CID Number.

ISSN: 1605-7422

ISSN: 2410-9045 (electronic)

ISBN: 9781628419443

Published by

SPIE

P.O. Box 10, Bellingham, Wa shington 98227-0010 USA

Telephone +1 3606763290 (Pacific Time)· Fax +1 3606471445

SPIE.org

Copyright () 2016, Society of Photo-Optic al Instrumentation Engineers.

Copying of material in this book for intemal or personal use, or for the intemal or personal use of specific clients, beyond the fair use provisions granted by the U.S. Copyright Law is authorized by SPIE subject to payment of copying fees. The Transactional Reporting Service base fee for this volume is $\$ 18.00$ per article (or portion thereof), which should be paid directly to the Copyright Clearance Center (CCC), 222 Rosewood Drive, Danvers, MA 01923. Payment may also be made electronically through CCC Online at copyright.com. Other copying for republication, resale, advertising or promotion, or any form of systematic or multiple reproduction of any material in this book is prohibited except with permission in writing from the publisher. The CCC fee code is $1605-7422 / 16 / \$ 18.00$.

Printed in the United States of America.

Public ation of record for individual papers is online in the SPIE Digital Library.

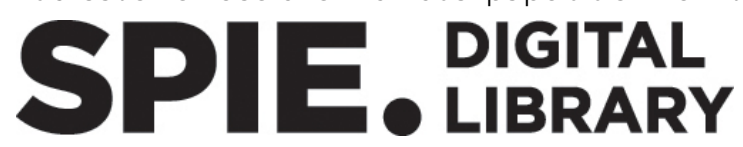

SPIEDigita lLibrary.org

Paper Numbering: Proceedings of SPIE follow an e-First publication model. A unique citation identifier (CID) number is assigned to each article at the time of publication. Utilization of CIDs allows articles to be fully citable as soon as they are published online, and connects the same identifier to all online and print versions of the publication. SPIE uses a six-digit CID article numbering system structured as follows:

- The first four digits correspond to the SPIE volume number.

- The last two digits indic a te publication order within the volume using a Base 36 numbering

system employing both numera ls a nd letters. These two-number sets start with $00,01,02,03,04$, 05, 06, 07, 08, 09, 0A, 0B ... 0Z, followed by 10-1Z, 20-2Z, etc. The CID Number appears on each page of the manuscript. 


\title{
Contents
}

\author{
vii Authors \\ ix Conference Committee \\ xiii Introduction
}

\section{CELLULAR AND EXTRACELLULAR MECHANICS}

971005 The endogenous fluorescence of fibroblast in collagen gels as indicator of stiffness of the extracellular matrix [9710-4]

971007 Online monitoring of mechanical properties of three-dimensional tissue engineered constructs for quality assessment [9710-6]

NOVEL METHODS II

9710 OA Dynamic phase-sensitive optical coherence elastography at a true kilohertz frame-rate [9710-9]

9710 OC Optical coherence elastography for human finger-pad skin deformation studies [9710-11]

9710 OD Lorentz force megahertz optical coherence elastography [9710-12]

\section{BRILLOUIN ELASTOGRAPHY}

$97100 \mathrm{G}$ High-speed elasticity-specific nonlinear Brillouin imaging/sensing via time-resolved optical (BISTRO) measurements [9710-15]

\section{ELASTOGRAPHY METHODS AND APPLICATIONS I}

$97100 \mathrm{M}$ Combined optical coherence tomography and optical coherence elastography for glomerulonephritis classification [9710-20]

9710 ON Depth-dependent displacement sensitivity analysis and the influence of Doppler angle for quantitative assessment of mechanical properties using phase-sensitive spectral domain optical coherence tomography [9710-21]

971000 Robust strain mapping in optical coherence elastography by combining local phase-resolved measurements and cumulative displacement tracking [9710-22] 
9710 OP Mechanical characterization of the mouse diaphragm with optical coherence elastography reveals fibrosis-related change of direction-dependent muscle tissue stiffness [9710-23]

\section{ELASTOGRAPHY METHODS AND APPLICATIONS II}

9710 OT Revealing anisotropic properties of cornea at different intraocular pressures using optical coherence elastography [9710-28]

\section{COMPUTATION AND MODELING IN ELASTOGRAPHY I}

9710 OX Effect of curvature and thickness on elastic wave velocity in cornea-like structures by FEM and OCE [9710-30]

9710 OY A comparative study of shear wave speed estimation techniques in optical coherence elastography applications [9710-31]

\section{COMPUTATION AND MODELING IN ELASTOGRAPHY II}

$97100 Z$ Experimental classification of surface waves in optical coherence elastography [9710-32]

971010 A three-dimensional solution for laser-induced thermoelastic deformation of the layered medium [9710-33]

\section{POSTER SESSION}

971013 Morphology and biomechanics of human heart [9710-45]

971014 Patient-specific modeling of human cardiovascular system elements [9710-46]

971015 Measurement of strain and strain rate in embryonic chick heart using spectral domain optical coherence tomography [9710-47]

971016 Skin surface and sub-surface strain and deformation imaging using optical coherence tomography and digital image correlation [9710-48]

\section{TISSUE MECHANICAL CONTRAST}

971019 Polarized spatial frequency domain imaging of heart valve fiber structure [9710-37]

$97101 \mathrm{~A}$ A comparison study of optical coherence elastography and laser Michelson vibrometry [9710-38] 
NOVEL METHODS III

$9710 \mathrm{lF} \quad$ Elasticity imaging of speckle-free tissue regions with moving acoustic radiation force and phase-sensitive optical coherence tomography [9710-43]

Proc. of SPIE Vol. $9710971001-5$

Downloaded From: https://www.spiedigitallibrary.org/conference-proceedings-of-spie on 26 Apr 2023 Terms of Use: https://www.spiedigitallibrary.org/terms-of-use 
Proc. of SPIE Vol. $9710971001-6$

Downloaded From: https://www.spiedigitallibrary.org/conference-proceedings-of-spie on 26 Apr 2023 Terms of Use: https://www.spiedigitallibrary.org/terms-of-use 


\section{Authors}

Numbers in the index correspond to the last two digits of the six-digit citation identifier (CID) article numbering system used in Proceedings of SPIE. The first four digits reflect the volume number. Base 36 numbering is employed for the last two digits and indicates the order of articles within the volume. Numbers start with 00, 01, 02, 03, 04, 05, 06, 07, 08, 09, OA, OB...0Z, followed by 10-1Z, 20-2Z, etc.

Aglyamov, Salavat R., OT, OX, 10 Alexandrov, Sergey, ON

Allen, Alicia, 19

Baba Ismail, Yanny M., 07

Bagnaninchi, Pierre O., 07

Ballman, Charles W., OG

Boadi, Joseph, OC

Byers, R., 16

Carré, Matt J., 0C, 16

Chang, Anthony, OM

Chelnokova, Natalia O., 13, 14

Chu, Ying-Ju, OY

Dou, Shidan, 15

Du, Yong, OM

El Haj, Alicia J., 07

Emelianov, Stanislav Y., 10

Franco, W., 05

Franklin, Steven E., OC, 16

Gelikonov, Grigory V., 00

Gerhardt, L. C., 16

Gladkova, Natalia D., 00

Golyadkina, Anastasiya A., 13, 14

Goth, Will, 19

Gubarkova, Ekaterina, 00

Han, Zhaolong, OD, OM, OT, OX

Hsieh, Bao-Yu, $1 \mathrm{~F}$

Hsu, Thomas, OM

Hu, Xuesong, 0C, 16

Ivanov, Dmitriy V., 13, 14

Kirillova, Irina $V_{\text {., }} 13,14$

Kistenev, Yury V., IA

Kossovich, Leonid Yu., 14

Larin, Kirill V., OA, OD, OM, OP, OT, OX, 10, 1A

Larina, Irina $\mathrm{V}_{\text {., }} \mathrm{OP}$

Leahy, Martin, ON

Lee, Z. S., 16

Lesicko, John, 19

Lewis, Roger, 0C, 16

$\mathrm{Li}$, Jiasong, OA, OD, OM, OT, OX, IA

Li, Wei, OC

Liang, Chengbo, 15

Liu, Chih-Hao, OA, OD, OM, OX, 1A

Liu, Jian, 15

Liu, X., 16

Loehr, James A., OP

Lynch, Gillian, ON

Ma, Zhenhe, 15

Maiti, Raman, 0C, 16

Matcher, Stephen J., 0C, 16

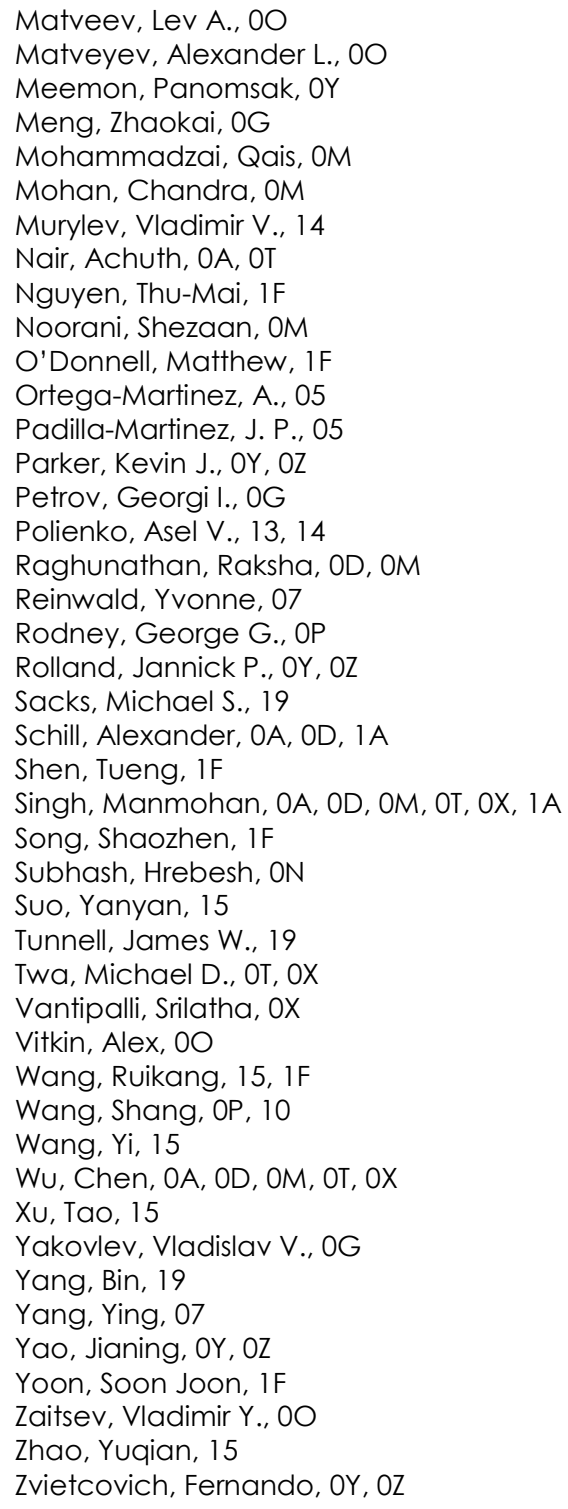


Proc. of SPIE Vol. $9710971001-8$

Downloaded From: https://www.spiedigitallibrary.org/conference-proceedings-of-spie on 26 Apr 2023 Terms of Use: https://www.spiedigitallibrary.org/terms-of-use 


\title{
Conference Committee
}

\author{
Symposium Chairs
}

James G. Fujimoto, Massachusetts Institute of Technology (United States)

R. Rox Anderson, Wellman Center for Photomedicine, Massachusetts General Hospital (United States) and Harvard School of Medicine (United States)

Program Track Chair

Steven L. Jacques, Oregon Health and Science University

(United States)

\section{Conference Chairs}

Kirill V. Larin, University of Houston (United States)

David D. Sampson, The University of Western Australia (Australia)

\section{Conference Program Committee}

Jeffrey C. Bamber, The Royal Marsden NHS Foundation Trust (United Kingdom)

Claude Boccara, Institut Langevin (France)

Stephen A. Boppart, University of Illinois at Urbana-Champaign (United States)

Brett E. Bouma, Wellman Center for Photomedicine, Massachusetts General Hospital (United States)

Zhongping Chen, Beckman Laser Institute and Medical Clinic (United States)

Donald D. Duncan, Portland State University (United States)

Kishan Dholakia, University of St. Andrews (United Kingdom)

Daniel S. Elson, Imperial College London (United Kingdom)

Mathias Fink, Institut Langevin (France)

Brendan F. Kennedy, The University of Western Australia (Australia)

Sean J. Kirkpatrick, Michigan Technological University (United States)

Seemantini K. Nadkarni, Harvard School of Medicine (United States)

Kentaro Nakamura, Tokyo Institute of Technology (Japan)

Amy L. Oldenburg, The University of North Carolina at Chapel Hill (United States)

Francesco S. Pavone, European Laboratory for Non-linear Spectroscopy (Italy)

Andrew E. Pelling, University of Ottawa (Canada)

Gabriel Popescu, University of Illinois at Urbana-Champaign (United States) 
Giuliano Scarcelli, University of Maryland (United States)

Gijs van Soest, Erasmus MC (Netherlands)

Victor X. D. Yang, Ryerson University (Canada)

Seok Hyun A. Yun, Wellman Center for Photomedicine, Massachusetts General Hospital (United States)

Ruikang K. Wang, University of Washington (United States)

Qifa Zhou, The University of Southern California (United States)

Session Chairs

1 Novel Methods I

Stephen A. Boppart, University of Illinois at Urbana-Champaign (United States)

Kishan Dholakia, University of St. Andrews (United Kingdom)

2 Cellular and Extracellular Mechanics

Seok Hyun A. Yun, Wellman Center for Photomedicine, Massachusetts General Hospital (United States)

Gabriel Popescu, University of Illinois at Urbana-Champaign (United States)

3 Novel Methods II

Amy L. Oldenburg, The University of North Carolina at Chapel Hill (United States)

4 Brillouin Elastography

Claude Boccara, Institut Langevin (France)

Ruikang K. Wang, University of Washington (United States)

$5 \quad$ Elastography Methods and Applications I

Qifa Zhou, The University of Southern California (United States)

Giuliano Scarcelli, University of Maryland (United States)

6 Elastography Methods and Applications II

Gijs van Soest, Erasmus MC (Netherlands)

Francesco S. Pavone, European Laboratory for Non-linear Spectroscopy (Italy)

Kentaro Nakamura, Tokyo Institute of Technology (Japan)

$7 \quad$ Keynote Session

David D. Sampson, The University of Western Australia (Australia)

8 Computation and Modeling in Elastography I

Brendan F. Kennedy, The University of Western Australia (Australia)

Mathias Fink, Institut Langevin (France)

9 Computation and Modeling in Elastography II

Jiang Zhu, Beckman Laser Institute and Medical Clinic (United States) 
Tissue Mechanical Contrast

Sean J. Kirkpatrick, Michigan Technological University (United States)

11 Novel Methods III

Donald D. Duncan, Portland State University (United States)

Seemantini K. Nadkarni, Harvard School of Medicine (United States)

Proc. of SPIE Vol. $9710971001-11$

Downloaded From: https://www.spiedigitallibrary.org/conference-proceedings-of-spie on 26 Apr 2023 Terms of Use: https://www.spiedigitallibrary.org/terms-of-use 
Proc. of SPIE Vol. $9710971001-12$

Downloaded From: https://www.spiedigitallibrary.org/conference-proceedings-of-spie on 26 Apr 2023 Terms of Use: https://www.spiedigitallibrary.org/terms-of-use 


\section{Introduction}

Optical elastography is the use of optics to characterize cells and tissues based on their mechanical properties. In utilizing the high-resolution capability of optics, this rapidly emerging field builds on and complements the related fields of ultrasound and MR elastography, as well as existing biomechanics methods, such as atomic force microscopy, cell indentation, micropipette aspiration, and particle rheology.

Mechanical forces play an important role in biological behavior and development at all spatial scales, from cells and their constituents to tissues and organs, and influence health, structural integrity, and normal function. High-resolution optical methods could help further the understanding of such mechanical interactions and properties in the cell mechanics and clinical diagnosis of a wide range of diseases. An important part of this contribution is expected to be the accurate determination of cell and tissue biomechanical properties, such as Young's or shear modulus.

This third annual conference continued the vibrant intellectual ambience of the first two conferences and displayed a strongly multidisciplinary character, bringing together technology and applications experts in bioengineering, biophysics, cell biology, clinical sciences, medical imaging, optics and photonics, and tissue engineering. This year, 49 contributed papers were built around 2.5 days of invited and contributed talks and posters. Exceptional keynote and invited speakers headlined the program:

\section{Keynote:}

Dennis E. Discher, University of Pennsylvania (United States), "Cells might not see where they are but they certainly feel the mechanics of their microenvironment!"

\section{Invited:}

Zhongping Chen, Beckman Laser Institute and Medical Clinic (United States), "Acoustic radiation force optical coherence elastography"

Brendan F. Kennedy, The University of Western Australia (Australia), "Compression optical coherence elastography for improved diagnosis of disease"

Seemantini K. Nadkarni, Harvard School of Medicine (United States), "Laser speckle rheology"

Assad A. Oberai, Rensselaer Polytechnic Institute (United States), "Inverse problems in biomechanical imaging" 
This year's keynote speaker, Dennis E. Discher, provided insight on biomechanics at the cellular level. He provided a comprehensive overview of the role of mechanical forces during everyday cellular activity. Special acknowledgement goes to Thorlabs, Inc., whose sponsorship supported this keynote session. Highlights of this year's contributed program include the progress and impact made in Brillouin microscopy, and in both the shear wave and compression-based optical coherence elastography approaches. Applications in the anterior eye continued to grow, with some important progress in breast cancer and interesting new approaches to imaging skin and scar mechanical properties.

Optical Elastography and Tissue Biomechanics has confirmed its important place in supporting this emerging area - we look forward with excitement and anticipation to see what the next twelve months will bring. In the meantime, please enjoy reading the papers submitted for this volume.

Kirill V. Larin David D. Sampson 